Joyce in Nighttown 



\section{MARK SHECHNER}

\section{Joyce in Nighttown}

A PSYCHOANALYTIC INQUIRY INTO ULYSSES

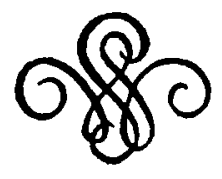

University of California Press

Berkeley - Los Angeles - London 
University of California Press

Berkeley and Los Angeles, California

University of California Press, Ltd.

London, England

Copyright (C) 1974, by

The Regents of the University of California

ISBN: 0-520-02398-6

Library of Congress Catalog Card Number: 72-95308

Printed in the United States of America 
For Anne 
